\title{
ANALYSIS OF MENSTRUAL CYCLE IRREGULARITIES IN ADOLESCENT GIRLS IN A TERTIARY CARE HOSPITAL
}

Asha Verma1, Rekha Mulchandani², Nupur Lauria ${ }^{3}$, Kusum Verma ${ }^{4}$, Sunita Himani ${ }^{5}$.
1. Professor, Department of Obstetrics \& Gynecology, SMS medical College Jaipur
2. Junior Specialist, Department of Obstetrics \& Gynecology, SMS medical College Jaipur
3. Professor, Department of Obstetrics \& Gynecology, SMS medical College Jaipur
4. Assistant Professor, Department of Obstetrics \& Gynecology, SMS medical College Jaipur
5. Assistant Professor, Department of Obstetrics \& Gynecology, SMS medical College Jaipur

\section{CORRESPONDING AUTHOR:}

Dr Asha Verma

Plot no.15Arjunpuri

Near Purshuram school, Imli Wala Phatak

Jaipur Rajasthan.

E-mail: ashaverma.cb@gmail.com

\section{HOW TO CITE THIS ARTICLE:}

Asha Verma, Rekha Mulchandani, Nupur Lauria, Kusum Verma, Sunita Himmani. "Analysis of Menstrual Cycle Irregularities in Adolescent Girls in a Tertiary Care Hospital.". Journal of Evolution of Medical and Dental Sciences 2013; Vol2, Issue 25, June 24; Page: 4638-4644.

\begin{abstract}
STUDY OBJECTIVE: The aim was to study the abnormal menstrual patterns of adolescent girls, the cause of dysfunction, and the associated factors in relation to the menstrual disorders. MATERIAL \& METHODS: A prospective study done in department of obstetrics \& gynaecology SMS Medical College from June 2010- June 2012. 120 adolescent girls between 12-19 yrs of age with menstrual disorders excluding dysmenorrhoea, primary amenorrhoea \&pregnancy related bleeding problems were included in the study. After detailed history, examination all had an ultrasound, thyroid profile \& serum prolactin levels. Other investigations done if required according to clinical profile of the patients RESULTS: 50\% of the girls presented at 18-19 years. 83.3\% attained menarche between 12-14 years of age Menorrhagia \& oligo- hypomenorrhea were the most common dysfunction, i.e $26.7 \%$ each, abnormal investigative profile was more common in patients with oligo hypomenorrhea, $40 \%$ of patients with oligo and/or hypomenorrhea had PCOS, $14 \%$ had hyperprolactinaemia,7\% had hypothyroidism. $1 / 3$ of these patients had normal hormonal \& USG findings. Majority (72.2\%) of the patients with menorrhagia and /or metrorrhagia had normal hormonal and USG findings. CONCLUSIONS: Evaluation of bleeding problems in adolescents is justified, before considering them as normal physiological transition. Although most problems are explained by anovulation other causes must be considered \& excluded Hormonal evaluation of these patients is justified \& reveals unsuspected pathology.
\end{abstract}

KEY WORDS: Menstrual dysfunction,adolescent girls,oligomenorrhoea,

INTRODUCTION: World Health Organization has defined 'adolescence' as a period between 10-19 years. In Indian context, adolescents constitute over $21.4 \%$ of the total population and this age group needs special attention because this period is very crucial since these are the formative years in the 
life of an individual when major physical, psychological and behavioral changes take place and additional roles and responsibilities are expected from them [1,2]. In many societies puberty onset is celebration time, it announces acquisition of fertility. However physiological social, cultural forces make it stressful, difficult transition for many. In India very little attention is paid to reproductive health of adolescent girls comprising 22\% females. Reasons for neglect are ignorance, indifference, reluctance of parents \& girls to consult a Doctor.

OBJECTIVES: This study was undertaken to evaluate abnormal menstrual patterns of adolescent girls, to investigate the cause of dysfunction, to study the associated factors in relation to the menstrual disorders.

MATERIAL \& METHODS: The study group consists of 120 adolescent girls with menstrual disorders excluding (dysmenorrhoea, primary amenorrhoea \& pregnancy related bleeding problems were included in the study. All patients underwent detailed history, examination, ultrasound \&analysis of hormonal status (thyroid profile, serum prolactin, other investigations were done if required depending on the clinical profile of the patients) at Department of obstetrics \& gynaecology SMS Medical college from June 2010 to June 2012. Common menstrual problems definitions are used to collect data $(3,4,5,6)$

REGULAR MENSTRUAL CYCLE: Cycle that occurs every $28 \pm 2-3$ days in which the menstrual flow lasts for 3-5 days with an average flow of 50- $200 \mathrm{ml}$. Irregular menstrual cycle: any deviation from cyclic occurrence of menstrual cycle i.e. $28 \pm 2-3$ days. Oligomenorrhea: very light menstruations, usually 4-9 periods per year. Menorrhagia: denotes bleeding, which is excessive in amount i. e. $>500 \mathrm{ml}$ (soaked pads $>5 /$ day) or periods that last longer than 7 days. Metrorrhagia: breakthrough bleeding or spot- ting in-between periods. Hypomenorrhea (scanty): denotes regularly timed bleeding but scanty $(<50 \mathrm{ml})$ in amount. Polymenorrhea was defined as a menstruation interval lasting less than 21 days.

STATISTICS: Table1 Chi-square $=40.39$ with 15 degrees of freedom; $\mathrm{P}=<0.001$.

Interpretation: Statistically significant difference was observed between different types of menstrual disorders and age. The proportion of cases of Menorrhagia was decreasing as age increases while proportion of cases of oligo and hypomenorrhoea, increased with age.

RESULTS: Common menstrual problems faced by these adolescents are given in Table 1. Out of 120 girls, frequency and percentages of common menstrual problems like oligomenorrhea, menorrhagia (profuse bleeding), oligo- hypomenorrhoea, metrorrhagia (break through bleeding), hypomenorrhea (scanty bleeding), polymenorrhea were 21(17.5\%), 32(26.7\%), 32(26.7\%), $22(18.3 \%), 8(6.6)$ and $5(4.2 \%)$ respectively.

Figure1 depicts the associated complaints with menstrual disorders. About 53\% patients had no associated complaints. Of the remaining $23 . \%$ patients presented with infertility \& hirsutism, obesity, acne, pain abdomen, weight loss\& hoarseness in 14\%, 13\%, 8\%, 2.5\%, 1.7\% \& $0.8 \%$ respectively

Fig 2 depicts the ultrasound findings in adolescent girls, with normal study, abnormal ovarian findings, and abnormal uterus findings in 50\%, 35\% and 15\% patients respectively 


\section{ORIGINAL ARTICLE}

Oligomenorrhoea \&/or hypomenorrhoea (58, 48.3\%): In this group associated complaints and the diagnosis were studied in detail as follows

Table 2 gives that of the oligo-hypomenorrhoea group, 15 (25.9\%) patients had obesity with/without hirsutism \& were diagnosed as PCOS, Hyperprolactinemia, Hypothyroidism, and Cushings syndrome in $86.7 \%, 20 \%, 20 \%$ and $6.7 \%$ respectively

Table 3 gives that of the oligo-hypomenorrhoea group,21 (36.2\%)patients had Infertility .Of these patients $42.9 \%$ patients had normal investigations, however $23.8 \%$ diagnosed as PCOS,14.3\% had Hyperprolactinemia,9.5\% had Endometriosis, ovarian cyst in 19\%,hydrosalpinx in 13.3\%, fibroid in $4.8 \%$

Table 4 gives that of the oligo-hypomenorrhoea group 7 (12.1\%) patients had only hirsutism. Of these patients $28.6 \%$ patients had normal investigations, however $42.8 \%$ diagnosed as PCOS, $14.3 \%$ had Hyperprolactinemia, and $9.5 \%$ had Endometriosis, multiple follicles in ovary in 14.3\%, hypothyroidism in $14.3 \%$, raised testosterone in $28.6 \%$.

Table 5 shows oligo-hypomenorrhoea group with no associated complaints. Of these $60 \%$ had normal investigations, $20 \%$ had PCOS, 13.3 had hyperprolactinemia \& $13.3 \%$ had ovarian cyst Table 6 shows diagnosis of girls with menorrhagia / metrorrhagia. Of these $90.7 \%$ had anaemia, 20\%had Hyperprolactinemia, 3.7\% had jaundice, 6.7\% had ITP, 1.9\% had PCOS \& ovarian cyst in $13.3 \%$.

DISCUSSION: The data shows $50 \%$ of the girls presented at $18-19$ years, $83.3 \%$ had attained menarche between 12-14 years of age. In this study Menorrhagia \& oligo-hypomenorrhoea were the most common dysfunction, i.e 26.7\% each. Mohite RV1etal(7) studied Out of 230 girls with attainment of menstruation, frequency and percentages of common menstrual problems like oligomenorrhea, menorrhagia , metrorrhagia, hypomenorrhea , dysmenorrhea and premen- strual syndrome were 37(16.08\%), 41(17.82\%), 63(27.39\%), 137(59.56\%), 113(49.13\%) and $107(46.52 \%)$ respectively

However abnormal investigative profile was more common in patients with oligo hypomenorrhoea. There was an overlap of two or more pathological conditions in few patients. Of those with oligo and or hypomenorrhoea 40\% of patients had PCOS. Arefi S 2001 (8)research shows that PCO was seen to be more common in adolescent girls with menstrual irregularity (42.5\%) with a tendency to be more frequent in oligomenorrhea-amenorrhea group than in polymenorrhea (51.6\% vs $25 \%$ ) In our study group of oligo-hypomenorrhoea $14 \%$ had hyperprolactinemia, $7 \%$ had hypothyroidism. Krassas GE (9) studied of the 171 hypothyroid patients, 131 (76.6\%) had regular cycles and $40(23.4 \%)$ irregular periods. Oligomenorrhoea and menorrhagia were the most common features in the latter group. Also one third had normal hormonal \& USG findings.

While majority (72.2\%) of the patients with menorrhagia and /or metrorrhagia had normal hormonal and USG findings..The present study shows that $1.9 \%(1 / 54)$ of puberty menorrhagia was due to polycystic ovarian disease. Rao (10) found $2.8 \%$ of the cause of puberty menorrhagia was due to polycystic ovarian disease. More than half of the girls were anaemic with $11.7 \%$ requiring blood transfusion. Bleeding disorder was detected in $2 \%$

Immune thrombocytopenia purpura (ITP) may also present with menorrhagia in the adolescent (associated with bruising, petechiae and mucosal bleeding) requiring specialist haematological assessment (Bevan et al, 2001(11). Claessens et al., 1981(12) studied 9 year audit of paediatric cases 
in the USA from 1971 to 1980 revealed that a primary coagulation disorder was found in almost 20\% of 59 patients admitted to a children's hospital for acute menorrhagia, where genital tract pathology had been excluded. One- quarter of those with severe menorrhagia (haemoglobin $<10 \mathrm{~g} / 100 \mathrm{ml}$ ), one-third of those requiring transfusion, and one-half of those presenting at menarche had such an underlying disorder. Bravender T, Emans SJ (13) studied in adolescents, the prevalence of a primary coagulation disorder requiring hospitalization for abnormal uterine bleeding ranges from $3 \%$ to $20 \%$

CONCLUSIONS: We found PCOS to be frequent endocrine mechanisms of menstrual disorders in teenagers Evaluation of bleeding problems observed in adolescents is justified, before considering them as normal physiological transition. Although most problems are explained by anovulation other causes must be considered \& excluded in a logical, evidence based \&cost effective manner. Hormonal evaluation of these patients is justified \& reveals unsuspected pathology

\section{REFERENCES:}

1. Hanson M, Gluckman P. Evolution: development and timing of puberty. Trends in Endocrinology \& Metabolism 2006; 17 (1): 7-12.

2. Kishore J. National Health Programs of India. Century publications, New Delhi; 5th ed. p5354.

3. Dutta DC. Textbook of Obstetrics, 20th ed .Central Book House publisher: 2010: p69.

4. Howkins and Bourne. Shaw's text book of Gynecology, 12th ed. Elsevier India Private Ltd: 2004: p 226.

5. Glueck CJ, Morrison JA, Daniels S, Wang P, Stroop D. Sex hormone-binding globulin, oligomenorrhea, polycystic ovary syndrome, and childhood insulin at age 14 years predict metabolic syndrome and class III obesity at age 24 years. J Pediatr 2011; 159(2):308-13.

6. Mackay HT. Abnormal menstrual bleeding. Current medical diagnosis and treatment. McGraw Hill 2005; 704.

7. JKIMSU, Vol. 2, No. 1, Jan-June 2013Common Menstrual Problems among Slum Adolescent Girls of Western Maharashtra, India Mohite RV1, Mohite VR2, Kumbhar SM1, Ganganahalli P1 1Dept. of Community Medicine

8. Arefi S. PCO Prevalence in adolescents with menstrual irregularity. J Reprod Infertil. 2001;2(1):57-62

9. Krassas GE, Pontikides N, Kaltsas T, Papadopoulou P, Paunkovic J, Paunkovic N, Duntas LH. Disturbances of menstruation in hypothyroidism Clinical Endocrinology Volume 50, Issue 5, pages 655-659, May 1999

10. Rao S, Pawar V, Badhwar VR, Fonseca MN. Medical intervention in puberty menorrhagia.BombayHospitalJournal2004;46(2)

11. Bevan, J.A., Maloney, K.W., Hillery, C.A., Gill, J.C., Montgomery, R.R. and Scott, J.P. (2001) Bleeding disorders: a common cause of menorrhagia in adolescents. J. Pediatr., 138, $856 \pm 861$.

12. Claessens, E.A. and Cowell, C.A. (1981). Acute adolescent menorrhagia. Am. J. Obstet. Gynecol., 139, 277 \pm 280 .

13. Bravender T, Emans SJ. Menstrual disorders: dysfunctional uterine bleeding. Pediatr Clin North Am 1999; 46(3): 545-53. 


\section{ORIGINAL ARTICLE}

Age wise Distribution of cases according to type of menstrual disorder

\begin{tabular}{|l|l|l|l|l|l|l|l|}
\hline Age Group & $\begin{array}{l}\text { Menorrh } \\
\text { agia } \\
\text { No \% }\end{array}$ & $\begin{array}{l}\text { Oligo- } \\
\text { hypomen } \\
\text { orrhoea } \\
\text { No \% }\end{array}$ & $\begin{array}{l}\text { Metrorr } \\
\text { hagia }\end{array}$ & $\begin{array}{l}\text { Oligome } \\
\text { norrhoea }\end{array}$ & $\begin{array}{l}\text { Hypome } \\
\text { norrhoe } \\
\text { a } \\
\text { No \% }\end{array}$ & $\begin{array}{l}\text { Polymen } \\
\text { orrhoea }\end{array}$ & Total \\
No \% & & & \\
\hline 12-13 yrs & $7(53.8)$ & $1(7.69)$ & $4(30.77)$ & $1(7.69)$ & 0 & 0 & 13 \\
\hline $\mathbf{1 4 - 1 5}$ yrs & $11(44)$ & $3(12)$ & $6(24)$ & $3(12)$ & 0 & $2(8)$ & 25 \\
\hline $\mathbf{1 6 - 1 7}$ yrs & $6(26.08)$ & $5(21.74)$ & $4(17.39)$ & $1(4.35)$ & $5(21.74)$ & $2(8.70)$ & 23 \\
\hline Total & $32(26.7)$ & $32(26.7)$ & $22(18.3)$ & $21(17.5)$ & $8(6.6)$ & $5(4.2)$ & 120 \\
\hline
\end{tabular}

Fig 1: Distribution of cases according to the associated complaints

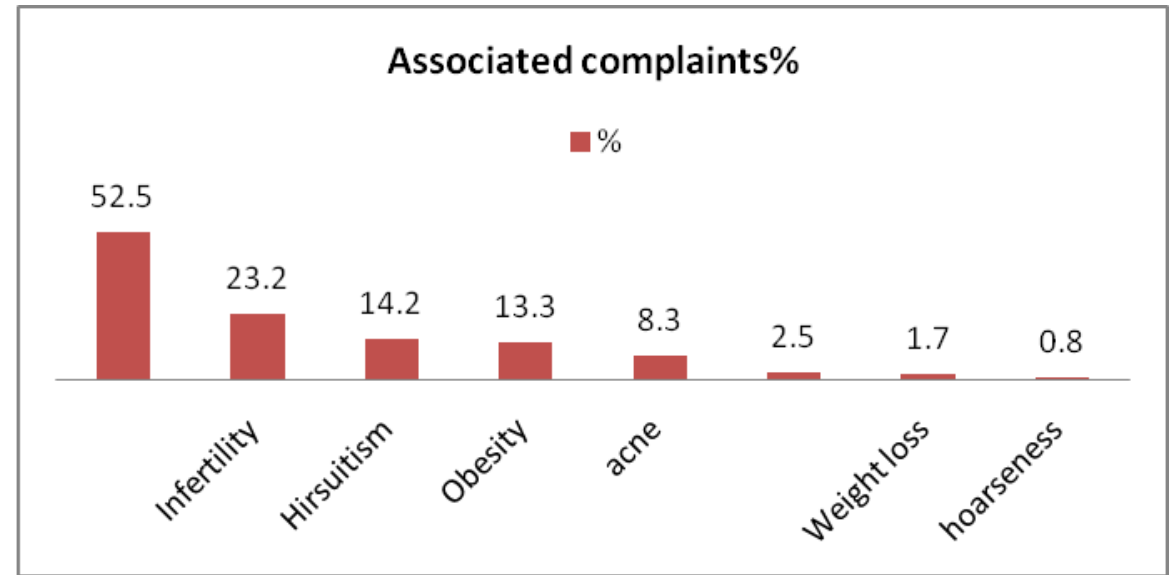

Fig 2: Distribution of cases according to USG findings

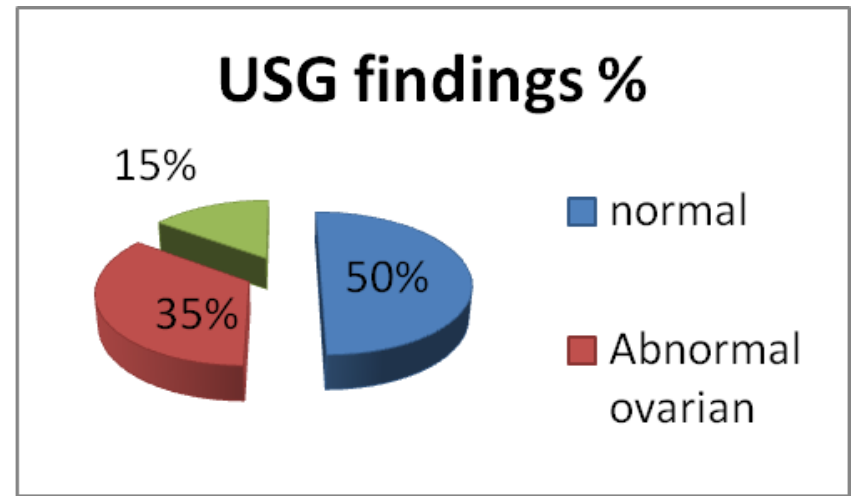




\section{ORIGINAL ARTICLE}

Table 2

\begin{tabular}{|l|l|l|l|l|l|l|}
\hline $\begin{array}{l}\text { Associated } \\
\text { complaints }\end{array}$ & investigations & $\mathbf{n o}$ & $\mathbf{\%}$ & Diagnosis & no & $\mathbf{\%}$ \\
\hline \multirow{2}{*}{$\begin{array}{l}\text { Obesity } \\
\text { with/ } \\
\text { without } \\
\text { hirsutism }\end{array}$} & normal & 0 & 0 & & & \\
\cline { 2 - 8 } $\mathbf{1 5 ( 2 5 . 9 \% )}$ & Increased LH/FSH & 4 & 26.7 & PCO & 13 & 86.7 \\
\cline { 2 - 8 } & Hyperprolactinemia & 3 & 20 & Hyperprolactinemia & 3 & 20 \\
\cline { 2 - 8 } & Increased TSH & 3 & 20 & Hypothyroidism & 3 & 20 \\
\cline { 2 - 8 } & Abnormal GTT & 3 & 20 & Cushings syndrome & 1 & 6.7 \\
\cline { 2 - 8 } & Increased cortisol & 3 & 20 & & & \\
\cline { 2 - 8 } & Increased insulin & 1 & 6.7 & & & \\
\cline { 2 - 8 } & USG & 13 & 86.7 & & & \\
\cline { 2 - 7 } & PCO & 2 & 13.3 & & & \\
\cline { 2 - 7 } & MFO & 2 & 13.3 & & & \\
\cline { 2 - 7 } & Thin endometrium & & & & & \\
\hline
\end{tabular}

Table 3

\begin{tabular}{|l|l|l|l|l|l|l|}
\hline $\begin{array}{l}\text { Associated } \\
\text { complaints }\end{array}$ & Investigations & no & $\mathbf{\%}$ & Diagnosis & no & $\mathbf{\%}$ \\
\hline $\begin{array}{l}\text { Infertility } \\
\mathbf{2 1 ( 3 6 . 2 \% )}\end{array}$ & normal & 9 & 42.9 & normal & 9 & 42.9 \\
\cline { 2 - 7 } & $\begin{array}{l}\text { Increased } \\
\text { prolactin }\end{array}$ & 3 & 14.3 & Hyperprolactinemia & 3 & 14.3 \\
\cline { 2 - 7 } & USG & & & Endometriosis & 2 & 9.5 \\
\cline { 2 - 7 } & PCO & 5 & 23.8 & PCOS & 5 & 23.8 \\
\cline { 2 - 7 } & Ovarian cyst & 4 & 19 & Ovarian cyst & 4 & 19 \\
\cline { 2 - 7 } & MFO & 1 & 4.8 & hydrosalpinx & 3 & 13.3 \\
\cline { 2 - 7 } & fibroid & 1 & 4.8 & fibroid & 1 & 4.8 \\
\hline
\end{tabular}

Table 4

\begin{tabular}{|l|l|l|l|l|l|l|}
\hline $\begin{array}{l}\text { Associated } \\
\text { complaints }\end{array}$ & investigations & no & $\mathbf{\%}$ & Diagnosis & no & \% \\
\hline \multirow{2}{*}{$\begin{array}{l}\text { Hirsuitism } \\
\mathbf{7}(12.1 \%)\end{array}$} & normal & 2 & 28.6 & normal & 2 & 28.6 \\
\cline { 2 - 7 } & USG & & & Endometriosis & 2 & 9.5 \\
\cline { 2 - 7 } & PCO & 3 & 42.8 & PCOS & 3 & 42.8 \\
\cline { 2 - 7 } & MFO & 1 & 14.3 & MFO & 1 & 14.3 \\
\cline { 2 - 7 } & Increased TSH & 1 & 14.3 & Hypothyroidism & 1 & 14.3 \\
\hline & $\begin{array}{l}\text { Increased } \\
\text { Testosterone }\end{array}$ & 2 & 28.6 & $\begin{array}{l}\text { Increased } \\
\text { Testosterone }\end{array}$ & 2 & 28.6 \\
\hline
\end{tabular}




\section{ORIGINAL ARTICLE}

Table 5

\begin{tabular}{|l|l|l|l|l|l|l|}
\hline $\begin{array}{l}\text { Associated } \\
\text { complaints }\end{array}$ & investigations & no & $\mathbf{\%}$ & Diagnosis & no & $\mathbf{\%}$ \\
\hline $\begin{array}{l}\text { None } \\
\mathbf{1 5}(\mathbf{2 5 . 9 \% )})\end{array}$ & normal & 9 & 60 & normal & 9 & 60 \\
\cline { 2 - 7 } & $\begin{array}{l}\text { Increased } \\
\text { LH/FSH }\end{array}$ & 3 & 20 & PCO & 3 & 20 \\
\cline { 2 - 7 } & $\begin{array}{l}\text { Increased } \\
\text { prolactin }\end{array}$ & 2 & 13.3 & Hyperprolactinemia & 2 & 13.3 \\
\cline { 2 - 7 } & Abnormal GTT & 1 & 6.7 & & & \\
\cline { 2 - 7 } & Increased cortisol & 1 & 6.7 & & & \\
\cline { 2 - 7 } & Increased insulin & 1 & 6.7 & & & \\
\cline { 2 - 7 } & USG & 2 & 13.3 & & & 13.3 \\
\cline { 2 - 7 } & PCO & 2 & 13.3 & & & \\
\cline { 2 - 7 } & MFO & 2 & 13.3 & Ovarian cyst & 2 & \\
\cline { 2 - 7 } & Ovarian cyst & & & & \\
\hline
\end{tabular}

Table 6 Investigations profile of patients with Menorrhagia and /Metrorrhagia group (54, 45\%)

\begin{tabular}{|l|l|l|l|l|l|}
\hline Investigations & no & \% & Diagnosis & no & \% \\
\hline Haemoglobin & 49 & 90.7 & anaemia & 49 & 90.7 \\
\hline Increased prolactin & 2 & 3.7 & Hyperprolactinemia & 3 & 20 \\
\hline Increased bilirubin & 2 & 3.7 & Jaundice & 2 & 3.7 \\
\hline Low platelets & 1 & 6.7 & ITP & 1 & 6.7 \\
\hline USG & & & & & \\
\hline $\begin{array}{l}\text { Thickened } \\
\text { endometrium }\end{array}$ & 5 & 9.3 & & & \\
\hline PCO & 1 & 1.9 & PCO & 1 & 1.9 \\
\hline MFO & 1 & 1.9 & & & \\
\hline Ovarian cyst & 3 & 5.6 & Ovarian cyst & 3 & 13.3 \\
\hline
\end{tabular}

